\title{
PERBEDAAN MINAT IBU HAMIL TRIMESTER III DALAM MENGGUNAKAN AKDR PASCA PLASENTA SEBELUM DAN SESUDAH PENYULUHAN (Di Desa Manyaran Kecamatan Banyakan Kabupaten Kediri)
}

Erma Herdyana, ${ }^{1}$ Wildan Husnunnisa, ${ }^{2}$

${ }^{1,2}$ Akademi Kebidanan Dharma Husada Kediri Jawa Timur

\begin{abstract}
ABSTRAK
AKDR pasca plasenta sebagai alat kontrasepsi efektif mempunyai kegagalan rendah dan dapat digunakan untuk menekan jumlah kelahiran. Penggunaan AKDR pasca plasenta di Indonesia masih terbilang jarang yang menggunakan dengan berbagai alasan. Tujuan penelitian ini adalah mengetahui perbedaan minat ibu hamil trimester III dalam menggunakan AKDR pasca plasenta sebelum dan sesudah penyuluhan di Desa Manyaran Kecamatan Banyakan Kabupaten Kediri.

Desain penelitian ini adalah pre-eksperimental dengan rancangan penelitian pra-pasca test. Penelitian ini dilaksanakan pada tanggal 19-21 Juni 2017. Populasi dalam penelitian ini adalah semua ibu hamil trimester III Desa Manyaran Kecamatan Banyakan Kabupaten Kediri, dengan teknik Total Sampling didapatkan sampel sebanyak 20 responden. Variabel penelitian ini adalah variabel independen yaitu penyuluhan dan variabel dependen yaitu minat ibu hamil trimester III dalam menggunakan AKDR pasca plasenta. Pengumpulan data menggunakan kuesioner, pengolahan data meliputi editing, coding, scoring, tabulating, dan dianalisis menggunakan uji Wilcoxon Match Pairs Test.

Hasil penelitian menunjukkan, minat ibu hamil trimester III sebelum penyuluhan adalah 15 responden (75\%) berminat tinggi, dan sesudah penyuluhan adalah 19 responden $(95 \%)$ berminat tinggi. Hasil uji statistik dengan Wilcoxon Match Pairs Test diperoleh $Z_{\text {hitung }}$ sebesar -3.900 dengan tingkat signifikansi $(\sigma)$ sebesar 0.000 atau $\rho$ value sebesar $0.000<\alpha 0,05$. H1 diterima yang artinya ada perbedaan minat ibu hamil trimester III dalam menggunakan AKDR pasca plasenta.

Dari hasil penelitian dapat disimpulkan ada perbedaan minat ibu hamil trimester III dalam menggunakan AKDR pasca plasenta sebelum dan sesudah penyuluhan di Desa Manyaran Kecamatan Banyakan Kabupaten Kediri. Dengan demikian diharapkan ibu hamil trimester III lebih berminat untuk menggunakan AKDR pasca plasenta sebagai alat kontrasepsi pilihannya.
\end{abstract}

Kata Kunci : $\quad$ Minat, Ibu Hamil Trimester III, AKDR Pasca Plasenta, Penyuluhan 


\section{Pendahuluan}

Berbagai usaha dibidang gerakan KB sebagai salah satu kegiatan pokok pembangunan keluarga sejahtera telah dilakukan baik oleh pemerintah, swasta, maupun masyarakat sendiri. Salah satunya dengan mensosialisasikan meotde kontrasepsi terkini yaitu AKDR post plasenta (pasca plasenta) oleh BKKBN. Metode AKDR pasca plasenta mempunyai keuntungan tersendiri, selain pemasangan lebih efektif karena dilakukan setelah plasenta lahir serta sekaligus mengurangi angka kesakitan ibu. Pada hasil expert meeting tahun 2009 dikatakan bahwa penggunaan AKDR pasca plasenta dan pasca keguguran perlu terus digalakkan karena sangat efektif mengingat angka kelahiran rata-rata 4.000.000 per tahun (BKKBN, 2014)

Akseptor KB aktif di Indonesia pada tahun 2015 yaitu 47.665.847 jiwa dengan presentase yaitu suntik $47,78 \%$, pil $23,60 \%$, IUD $10,73 \%$, implan 10,58 \%, MOW 3,49\%, kondom 3,16\%, MOP 0,43 \%. (Kementrian Kesehatan Indonesia, 2015).

Provinsi Jawa Timur tahun 2015 terlihat bahwa kepesertaan KB masih didominasi oleh Non MKJP (Metode Kontrasepsi Jangka Panjang) dari pada yang MKJP, yang mana hal ini berpengaruh pada keberlangsungan berKB. Suntuk $58,4 \%$, pil $17,3 \%$, , IUD $11,4 \%$, implan 8,3 \%, MOW 2,1 $\% \quad$ Kondom $1,7 \%$, MOP $0,8 \%$. Dan pada tahun 2015 akseptor KB AKDR pasca plasenta mencapai 20.031 jiwa dengan prosentase $13,35 \%$ (Profil Jawa Timur, 2015).

Berdesarkan data KB di Kabupaten Kediri pada bulan Maret 2015 jumlah peserta KB aktif yaitu 240.341 jiwa dengan suntik $54,17 \%$, pil 16,00 $\%$, IUD $14,13 \%$, impalan 7,6 \%, , MOW 6,40 \% , MOW 6,40 \%, kondom $1.37 \%$, dan MOP 0,09 $\%$. Di Kabupaten Kediri pengguna kontrasepsi AKDR pascapersalinan sebanyak 37,06\% (Dinas Kesehatan Kabupaten Kediri, 2015).

Di Indonesia sendiri, Keluarga Berencana (KB) pasca plasenta merupakan salah satu program pemerintah yang memiliki terger sebesar $80 \%$, sedangkan jumlah peserta $\mathrm{KB}$ pasca plasenta di Indonesia baru mencapai 30\% daari $80 \%$ target tersebut. Jumlah ini dinilai oleh Mentri Kesehatan RI sudah merupakan Kemajuan yang cukup bagus untuk membantu meningkatkan jumlah perserta Keluarga Berencana (KB). Tetapi apabila dilihat dari target pemerintah masih sangat jauh dari harapan yang diinginkan. Jumlah peserta Keluarga Berencana (KB) di Kediri pada tahun 2015 sebanyak 32,352 $(66,6 \%)$.

Rendahya cakupan akseptor KB AKDR pasca plasenta saat ini dapat memengaruhi AKI dan AKB di Indonesia. Berdasarkan Studi Lancet di negara-negara dengan tingkat kelahiran yang tinggi, KB sangat bermanfaat baik untuk kesehatan ibu dan bayi, dimana diperkirakan dapat menunkan angka kematian ibu dengan mencegah kehamilan yang tidak diinginkan dan dapan menurutkan angka kematian anak dengan mengurangi jarak persalinan kurang dari 2 tahun (Buletin Jendela Data, 2013)

Kurangnya pemahaman dan pengetahuan ibu hamil trimester III mengenai kontrasepsi AKDR pasca plasenta dipengaruhi oleh kurangnya informasi tentang AKDR pasca plasenta, sehingga dampak dari ketidaktauan tentang kontrasepsi AKDR pasca plasenta dapat menimbulkan kecemasan dan ketakutan yang berlebihan saat mengalami salah satu efek samping dari penggunaan kontrasepsi tersebut.

Salah satu bentuk upaya untuk menanggulaingi masalah diatas adalah dengan dilakukan penyuluhan ataupun konseling oleh petugas kesehatan setempat tentang pengertian, jenis, mekanisme kerja. Efektifitas, keuntungan dan kerugian, persyaratan pemakaian, kunjungan ulang maupun informasi umum. Karena penyuluhan dan konseling merupakan bagian integral yang sangat penting dalam pelayanan keluarga berencana, . Pendekatan pada saat penyuluhan akan mendorong komunikasi yang terbuka antara klien dengan tenaga kesehatan, sehingga klien akan mudah untuk memahami materi yang disampaikan oleh tenaga kesehatan mengenai kontrasepsi AKDR pasca plasenta.

Berdasarkan studi pendahuluan pada tanggal 22 April 2017 di Desa Manyaran Kecamatan Banyakan Kabupaten Kediri dilakukan wawancara pada $10 \mathrm{ibu}$ hamil trimester III. Dimana dari hasil wawancara yang dilakukan semuanya menyatakan kurang berminat menggunakan kontrasepsi AKDR pasca plasenta. Semuanya mengatakan enggan untuk memakai kontrasepsi AKDR pasca plasenta 
dikarenakan takut akan efek samping dan takut dapat mengganggu saat berhubungan suami istri.

\section{Metode}

Rancangan penelitian yang digunakan adalah pre-eksperimental yang jenis rancanganya pre- posttes dalam satu kelompok (one-Group preposttest design) penelitian ini menggunakan sampel semua ibu hamil trimester III di Desa Manyaran, Kecamatan Banyakan, Kabupaten Kediri.

Hasil

Tabel 1:Karakteristik Responden Berdasarkan Umur di Desa Manyaran, Kecamatan Banyakan, Kabupaten Kediri.

\begin{tabular}{llcc} 
No. & Umur (Tahun) & Frekuensi & Prosentase (\%) \\
\hline 1. & $<20$ & 4 & 20 \\
\hline 2. & $21-49$ & 16 & 80 \\
\hline 3. & $>49$ & 0 & 0 \\
\hline Total & & 20 & 100
\end{tabular}

Berdasarkan tabel diatas menunjukkan bahwa karakteristik tertinggi berdasarkan umur adalah

responden yang mempunyai umur 21-49 tahun sebanyak 16 responden $(80 \%)$.

Tabel 2: Karakteristik Responden Berdasarkan Tingkat Pendidikan di Desa Manyaran, Kecamatan Banyakan, Kabupaten Kediri

\begin{tabular}{|c|c|c|c|}
\hline No & Pendidikan & Frekuensi & Presentase (\%) \\
\hline 1 & Tidak Sekolah & 0 & 0 \\
\hline 2 & SD & 2 & 10 \\
\hline 3 & SMP & 9 & 45 \\
\hline 4 & SMA & 9 & 45 \\
\hline \multirow[t]{2}{*}{5} & Ademi / Perguruan Tinggi & 0 & 0 \\
\hline & Total & 20 & 100 \\
\hline
\end{tabular}

Berdasarkan tabel diatas dapat diketahui bahwa dari 20 responden karakteristik pendidikan yaitu ibu hamil trimester III 2 responden
$(10 \%)$ berpendidikan SD, 9 responden $(45 \%)$ berpendidikan SMP dan SMA.

\section{a. Karakteristik Responden Berdasarkan Pekerjaan Istri}

Tabel .3: Karakteristik Responden Berdasarkan Pekerjaan di Desa Manyaran Kecamatan Banyakan Kabupaten Kediri

\begin{tabular}{clcc} 
No & Pekerjaan & Frekuensi & Presentase (\%) \\
\hline 1 & PNS & 0 & 0 \\
\hline 2 & Swasta & 3 & 15 \\
\hline 3 & Wiraswasta & 0 & 0 \\
\hline 4 & Ibu Rumah Tangga & 17 & 85 \\
\hline & Total & 20 & 100
\end{tabular}


Berdasarkan tabel diatas diketahui bahwa dari 20 responden, karakteristik pekerjaan ibu hamil trimester III tertinggi yaitu IRT sebanyak 17 responden (85\%). Sedangkan karakteristik pekerjaan ibu hamil trimester III terendah yaitu PNS dan wiraswasta sebanyak 0 responden $(0 \%)$.

Tabel.4: Karakteristik Responden Berdasarkan Pernah/ Tidak pernah mendapatkan Informasi di di Desa Manyaran Kecamatan Banyakan Kabupaten Kediri

\begin{tabular}{llcc} 
No & Informasi & Frekuensi & Presentase (\%) \\
\hline 1 & Pernah & 11 & 55 \\
\hline 2 & Tidak Pernah & 9 & 45 \\
\hline & Total & 20 & 100
\end{tabular}

Berdasarkan tabel diatas dari 20 responden 11 (55\%) ibu hamil trrimester III sudah pernah mendapatkan informasi mengenai AKDR pasca plasenta, sedangkan 9 responden $(45 \%)$ ibu hamil trimester III tidak pernah mendapatkan informasi tentang AKDR pasca plasenta.

Tabel .5: $\quad$ Karakteristik responden Berdasarkan Sumber Informasi di di Desa Manyaran Kecamatan Banyakan Kabupaten Kediri

\begin{tabular}{|c|c|c|c|}
\hline No & Informasi & Frekuensi & Presentase (\%) \\
\hline 1 & Bidan & 4 & 36,36 \\
\hline 2 & Media Massa & 1 & 9,10 \\
\hline 3 & Tetangga & 3 & 27,27 \\
\hline 4 & Internet & 3 & 27,27 \\
\hline & Total & 11 & 100 \\
\hline
\end{tabular}

Berdasarkan tabel diatas dari 11 diketahui ibu hamil trimester III mendapat informasi tertinggi dari bidan yaitu sebanyak 4 responden $(36,36 \%)$, sedangkan yang paling rendah yaitu ibu hamil trimester III yang mendapat infornasi dari media masa yaitu sebanyak 1 responden $(9,10 \%)$.

Tabel 8: Tabel Silang Perbedaan Ibu Hamil Trimester III Dalam Menggunakan AKDR Pasca Persalinan Sebelum dan Sesudah Penyuluhan di Desa Manyaran Kecamatan Banyakan Kabupaten Manyaran

\begin{tabular}{|c|c|c|c|c|c|}
\hline \multirow{3}{*}{ No } & \multirow{3}{*}{$\begin{array}{c}\text { Kriteria } \\
\text { Minat }\end{array}$} & \multicolumn{4}{|c|}{ Minat } \\
\hline & & \multicolumn{2}{|c|}{ Sebelum } & \multicolumn{2}{|c|}{ Sesudah } \\
\hline & & $\sum$ & $\%$ & $\sum$ & $\%$ \\
\hline 1. & Tinggi & 15 & 75 & 19 & 95 \\
\hline 2. & Sedang & 5 & 25 & 1 & 5 \\
\hline 3. & Rendah & 0 & 0 & 0 & 0 \\
\hline & Total & 20 & 100 & 20 & 100 \\
\hline
\end{tabular}

Hasil Uji Wilcoxon Signed Ranks Test $\quad$ Sig.(2-tailed) $=0,000<\alpha 0.05$

Berdasarkan tabel IV.11 diketahui bahwa sebelum diberi penyuluhan dari 20 responden didapatkan 15 responden $(75 \%)$ memiliki minat tinggi, 5 responden $(25 \%)$ memiliki minat sedang, dan tidak terdapat responden yang memiliki minat rendah. Sedangkan sesudah diberi penyuluhan dari 20 responden didapatkan 19 responden (95\%) memiliki minat tinggi, 1 responden $(5 \%)$ memiliki minat sedang dalam 
menggunakan AKDR pasca plasenta, dan tidak Diskusi

Berdasarkan dari hasil penghitungan
statistik yang telah dilakukan dengan menggunakan menggunakan SPSS 20 dan dengan uji Wilcoxon Match Pair Test pada 20 responden, setelah dimasukkan rumus $Z_{\text {hitung }}$ maka diperoleh $Z_{\text {hitung }}$ sebesar -3.900 dengan tingkat signifikansi $(\sigma)$ sebesar 0.000 atau $\rho$ value sebesar $0.000<\alpha 0,05$. Karena nilai $\sigma \leq$ 0,05 , maka $\mathrm{H} 1$ diterima yang artinya ada perbedaan minat ibu hamil trimester III dalam menggunakan AKDR pasca plasenta sebelum dan sesudah penyuluhan di Desa Manyaran Kecamatan Banyakan Kabupaten Kediri.

Penyuluhan kesehatan adalah kegiatan pendidikan kesehatan yang dilakukan dengan menyebarkan pesan, menanamkan keyakinan, sehingga masyarakat tidak hanya sadar, tahu dan mengerti tetapi mau dan melakukan suatu anjuran yang ada hubungannya dengan kesehatan (Suryani, 20010:59).

Bentuk penyuluhan yang menarik mempengaruhi keberhasilan dalam penyuluhan, metode ceramah yang digunakan untuk penyuluhan menggunakan bahasa yang sopan dan mudah dimengerti responden dan menyisipkan intermezo atau sedikit humor saat penyuluhan sehingga responden tidak mudah bosan. Memberikan kesempatan untuk bertanya jawab yang berkaitan dengan materi, serta menggunakan alat bantu leaflet untuk memudahlan responden dalam menerima materi. Sehingga cara tersebut dapat membantu berlangsungnya penyuluhan dan tujuan dari penyuluhan itu sendiri dapat tercapai yaitu meningkatkan minat ibu hamil trimester III dalam menggunakan AKDR pasca plasenta.

Perbedaan yang tampak signifikan setelah diberikan penyuluhan memperlihatkan bahwa responden mampu menangkap informasi yang disampaikan melalui penyuluhan.

Adanya peningkatan minat diatas dapat ditunjukkan pada kuesioner dengan kriteria soal pengetahuan yang terdapat pada soal nomor 1620 dari 20 responden sebelum penyuluhan, mayoritas responden menjawab benar. Sedangkan sesudah penyuluhan terjadi terdapat responden yang memiliki minat rendah.

peningkatan pengetahuan ibu hamil trimester III tentang AKDR pasca plasenta.

Selain dari pengetahuan, salah satu fator lain yang juga berpengaruh terhadap minat seseorang adalah motivasi. Berdasarkan hasil penelitian sebelum diberikan penyuluhan didapatkan bahwa motivasi ibu hamil trimester III terhadap penggunaan AKDR pasca plasenta termasuk dalam kategori sedang yaitu 10 responden $(50 \%)$, tinggi 10 responden $(50 \%)$, dan tidak ada responden yang memiliki motivas rendah. Sedangkan sesudah diberikan penyuluhan didapatkan hasil penelitian bahwa motivasi ibu hamil trimester III yang termasuk dalam kategori tinggi 14 responden (70\%), kategori sedang 6 responden (30\%) dan tidak ada responden yang memiliki motivasi rendah.

Motivasi berhubungan erat dengan kebutuhan, motif, dan tujuan sangat mempengarui kegiaatan dan hasil belajar. Motivasi sangat penting karena motivasi menggerakkan organisme, mengarahkan tindakan, serta memilih tujuan yang dirasa paling berguna bagi kehidupan individu. Jika motivasi seseorang untuk berhasil lebih kuat daripada motivasi untuk gagal, maka ia akan memerinci kesulitan-kesulitan yang dihadapinya. (Soemanto, 2008)

Keinginan dari ibu sendiri muncul ketika ada dorongan dari ibu untuk mengetahui AKDR pasca plasenta, entah dari keluarga, teman, tetangga maupun tenaga kesehatan. Oleh karena itu ibu akan lebih memhatikan kelebihankelebihan dan kekurangan dari AKDR pasca plasenta. Untuk selanjudnya dipilah-pilah mana menurut mereka yang pantas untuk dijadikan pilihan kontrasepsi dan pasti melewati proses penyaringan yang lebih baik menurut ibu.

Namun tidak semua kalangan masyarakat mau meluangkan waktu sedikit saja untuk mencari informasi dikarenakan presepsi yang terlanjur melekat di kalangan masyarakat bahwa datang kepetugas kesehatan adalah pilihan terakhir yang akan di tempuh. Tetapi tidak sedikit juga masyarakat yang menyadari bertapa pentingnya mendapat informasi langsung dari tenaga 
kesehatan. Selain informasi yang didapat akan lebih akurat, hal itupun dapat memantapkan hati ibu untuk menentukan pilihannya dalam menggunakn AKDR pasca plasenta.

Untuk meningkatkan minat seseorang perlu adanya dorongan dan motivasi, terutama dari tenaga kesehatan diharapkan dapat berperan aktif dalam memberikan motivasi kepadan responden untuk menggunakan kontrasepsi

\section{Daftar Pustaka}

Denantika O, Serudji J, Revilla Gusti Hubungan Status Gravida Ibu Terhadap Kejadian Preeklamsia di Fakultas Kedokteran Andalas Padang . Jurnal andalas. Vol 4 No. 1 Februari 2015 hal 212-213.

Hidayat, AAA. 2012. Riset Keperwatan Dan Teknik Penulisan Ilmiah. Jakarta : Salemba Medika.

JNPK-KR, 2008. Asuhan Persalinan Normal. Jakarta : Tim Revisi.

Lubis, NL, 2013. Psikologi Kespro Wanita Dan Perkembangan Reproduksinya. Jakarta : Kencana Perdana Media Group.

Manuaba, 2010. Ilmu Kebidanan, Penyakit Kandungan, Dan KB. Jakarta : EGC.

Marmi,et al. 2015. Asuhan Kebidanan Patologi. Yogyakarta : Pustaka Pelajar.

Notoatmodjo, S, 2010. Metodologi Penelitian Kesehatan. Jakarta : Rineka Cipta. 2012. Metodologi Penelitian Kesehatan. Jakarta : Rineka Cipta.

Nursal, Tamela, Fitrayeni Faktor Risiko Preeklampsia Pada Ibu Hamil Jurnal Kesehatan Masyarakat Andalas, Vol. 10, No. 1Oktober 2015 Maret hal. 38-44.

Nursalam, 2013. Metode Penelitian Ilmu Keperawatan. Jakarta: Salemba Medika

Padila, 2014. Keperawatan Maternitas. Yogyakarta: Nuha Medika.

2015. Asuhan Keperawatan Maternitas

II.Yogyakarta: Nuha Medika.

Purwaningsih, 2010. Asuhan Keperawatan Maternitas. Yogyakarta : Nuha Medika.

Pratiwi, CS, 2013.Faktor Resiko Ibu Hamil. Yogyakarta. Prodi DIII Kebidanan STIKES “ Aisyiyah.

Prawirohardjo,S,2009. Ilmu Kebidanan. Jakarta: PT Bina Pustaka Sarwono Prawirohardjo. 2013. Ilmu kebidanan. Jakarta: PT Bina

Pustaka Sarwono Prawirohardjo.

Radjamuda N, Montolalu A. Faktor-Faktor Risiko Yang Berhubungan Dengan Kejadian Hipertensi
AKDR baik melalui penyuluhan maupun konseling.

\section{Simpulan}

Terdapat perbedaan minat ibu hamil trimester III dalam menggunakan AKDR pasca plasenta sebelum dan sesudah penyuluhan yaitu $75 \%$ dan $95 \%$

Pada Ibu Hamil Di Poli Klinik Obs-Gin Rumah Sakit Jiwa Prof. Dr. V. L. Ratumbuysang Kota Manado. Jurnal Ilmiah Bidan. Vol. 2 No.1. Januari - Juni 2014.

Rakorpok Kementrian Kesehatan Ri, 2015. Kesehatan Dalam KerangkaSustainable Development Goals (SDGs). Jakarta.

Rukiah, A, et al. 2009. Asuhan Kebidanan II Persalinan. Jakarta: Trans Info Media.

Sabarguan, 2008. Karya Tulis Ilmiah Untuk Mahasiswa D3 Kebidanan. Jakarta : Anggota IKAPI.

Sastroasmoro,2008. Dasar-dasar metode penelitian klinis. Jakarta: CV Sugeng Sefa.

Sofian, A. 2013. Sinopsis Obstetri Jilid I. Jakarta EGC.

Sugiono,2012. Stastitika untuk penelitian. Bandung: Alfabeta.

Varney,H,2007. Buku Ajar Asuhan Kebidanan. Jakarta: EGC.

Wulandari, E, Wijayanti,2014. Jurnal Keperawatan, Vol 1, No.1.

Yogi ED , Haryanto, Sonbay E. Hubungan Antara Usia Dengan Preeklamsia Pada Ibu Hamil Di Poli KIA RSUD Kefamenanuka Kabupaten Timor Tengah Utara. Jurnal Delima Harapan, Vol 3, No.2 Agustus-Januari 2014 hal 10-19.

Noveliza.2012.Grandemultipara.https://midwiferyfo nynoveliza.wordpress.com/2012/06/29/grandemulti para. [akses 22 Mei 2016].

Salwa.2016.Hubungan Diabetus Melitus Dengan Preeklampsia.

http;//www.diabetics1.com/2016/03/hubungan-

diabetes-dengan-preeklampsia. [Akses 18 Mei 2016]

Suwanti, Edi Prasetyo Wibowo, \& Nur Aini Safitri. (2012) Hubungan Tekanan Darah Dan Paritas Dengan Kejadian Preklampsia Di Ruang Bersalin RSUP NTB Tahun 2012. Media Bina Ilmiah . Volume 8, No. 1, Februari 2014. ISSN No. 19783787. Pp 25-30. 